\title{
Electronic and photovoltaic properties of new materials based on imidazo[1,2-a]pyrazine. Computational investigations
}

\author{
A.Zahlou ${ }^{* * *}$, S.Chtita ${ }_{* * *}^{* *}$ M.Ghamali ${ }_{* * *}^{* *}$ L.Bejjit ${ }^{*}$, \\ T.Lakhlifi ${ }^{* * *}$, Mr.Bouachrine \\ *LASMAR, Faculte des Sciences, \\ University Moulay Ismail Meknes, Marocco \\ *:*STM, University Moulay Ismail, Meknes, Morocco \\ Molecular Chemistry and Natural Substances Laboratory, \\ Faculty of Science, University Moulay Ismail, Meknes, Morocco
}

\section{Received August 1, 2013}

\begin{abstract}
A quantum chemical investigation has been performed to explore optical and electronic properties of a series of different compounds based $\pi$-conjugated molecular materials with fused rings, on imidazo[1,2-a]pyrazines. Different electron-donor side groups as side-chain substituents were introduced in molecular backbone to investigate their effects on the electronic structure. The HOMO and LUMO energy levels as well energy gap $E_{g}$ of the studied compounds have been calculated and reported. The obtained data suggest that studied molecules are good candidates for organic solar cells.
\end{abstract}

С использованием квантово-химических методов рассчитаны оптические и электронные свойства соединений на основе ароматических молекул с $\pi$-сопряженными связями, а именно имидазо[1,2 а]пиразина. Различные электроно-донорные группы вводились в молекулярную систему для изучения влияния на электронную структуру молекул. Рассчитаны HOMO и LUMO энергетические уровни, а также ширина запрещенной зоны $E_{g}$ изученных соединений. Результаты исследований позволяют рассматривать эти соединения в качестве перспективных для использования в органических солнечных элементах.

Електронні $і$ фотогальванічні властивості нових матеріалів на основі имидазо[1.2-а]піразину. Комп'ютерне моделювання. А.Захлоу, С.Чтита, М.Халалі, Л.Беджит, Т.Лакхлірі, М.Боучріні.

3 використанням квантово-хімічних методів розраховано оптичні і електронні властивості низки сполук на основі ароматичних молекул з $\pi$-спряженими звіязками, зокрема імідазо[1,2а]піразіну. Різні бокові електронодонорні групи введено у молекулярну систему для вивчення впливу на електронну структуру молекул. Розраховано НОМО i LUMO енергетичні рівні, а також ширину забороненої зони $E_{g}$ досліджених сполук . Результати дослідженя дозволяють розглядати ці сполуки як перспективні при використанні в органічних сонячних елементах.

\section{Introduction}

The interest in $\pi$-conjugated polymers increased considerably after discovery that their electrical conductivity increases sub- stantially upon electrochemical doping. This discovery led to the 2000 Nobel Prize in Chemistry awarded to Alan Heeger, Alan Mac Diarmid, and Hideki Shirakawa [1]. By the mid-1980s, several research teams in 
<smiles>Cc1cn2c(Br)c(-c3ccc(F)cc3)nc2cn1</smiles>

1<smiles>Cc1cn2c(C#N)c(-c3ccc(F)cc3)nc2cn1</smiles>

2<smiles>Cc1cn2c(CN3CCCCC3)c(-c3ccccc3)nc2cn1</smiles><smiles>Cc1cn2c(CN3CCOCC3)c(-c3ccc(F)cc3)nc2cn1</smiles><smiles>Cc1cn2c(CO)c(-c3cc4ccccc4oc3=O)nc2cn1</smiles>

5

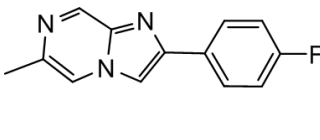

6

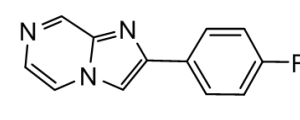

7<smiles>Brc1c(-c2ccccc2)nc2cnccn12</smiles>

11<smiles>Cc1cn2c(Br)c(-c3ccccc3)nc2cn1</smiles>

8<smiles>Fc1ccc(-c2nc3cnccn3c2Br)cc1</smiles>

12

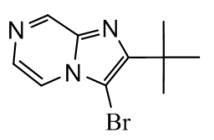

13

Fig. 1. Structure of the studied imidazo[1,2-a]pyrazines derivatives.

both academia and industry were investigating $\pi$-conjugated small molecules and polymers to gain benefit of their unique optical and semiconducting properties [2]. The development of organic semiconductors has focused on organic $\pi$-conjugated molecules for application in electronic and photonic devices by virtue of their ability to afford high operating speeds, large device densities, low cost, and large area flexible circuits. These materials which may have interesting optical and electronic properties for applications in microelectronics such as organic field-effect transistor (OFET), lightemitting diodes, sensors, photo-detectors and solar cells [2].

In photovoltaic, one of the most critical issues, besides achieving adequate efficiencies and life times, is to reduce the costs associated with achieving economies of scale. Organic solar cells, which can be processed from solution, have great potential to reach the goal of photovoltaic technology that is economically viable for largescale power generation, where the organic materials are the key elements for converting light into electricity. Organic photovoltaic materials have many advantages compared to inorganic semiconductors. They are a subject of an increasing interest in recent years due to their advantages of low cost, light weight, processability of the organic materials and potential to make flexible photovoltaic devices in comparison with the traditional silicon-based solar cells. The mismatch between absorption spectra, low band gap and the solar irradiance spectrum is one of the main reasons for low efficiency and high performance of the organic solar cells devices [3, 4].

In this paper, thirteen compounds based on imidazo[1,2-a]pyrazines $(1,2,3,4,5,6$, 7, 8, 9, 10, 11, 12 and 13 (shown Fig. 1), are designed. The geometries, electronic properties, absorption and emission spectra of these studied compounds are studied by using density functional theory (DFT) and time-dependent density functional theory (TD/DFT) with the goal to find potential sensitizers for use in organic solar cells.

\section{Theoretical methodology}

DFT method of three-parameter compound of Becke (B3LYP) [5] was used in the study of the neutral and polaronic compounds. The 6-31G (d) basis set was used for all calculations [6]. To obtain the charged structures, we start from the optimized structures of the neutral form. The calculations were carried out using Gaussian 03 program [7]. Geometry structures of the neutral and doped molecules were optimized under no constraint. We have also examined HOMO and LUMO levels; the energy $\mathrm{E}_{\text {gap }}$ is evaluated as the difference between the HOMO and LUMO 

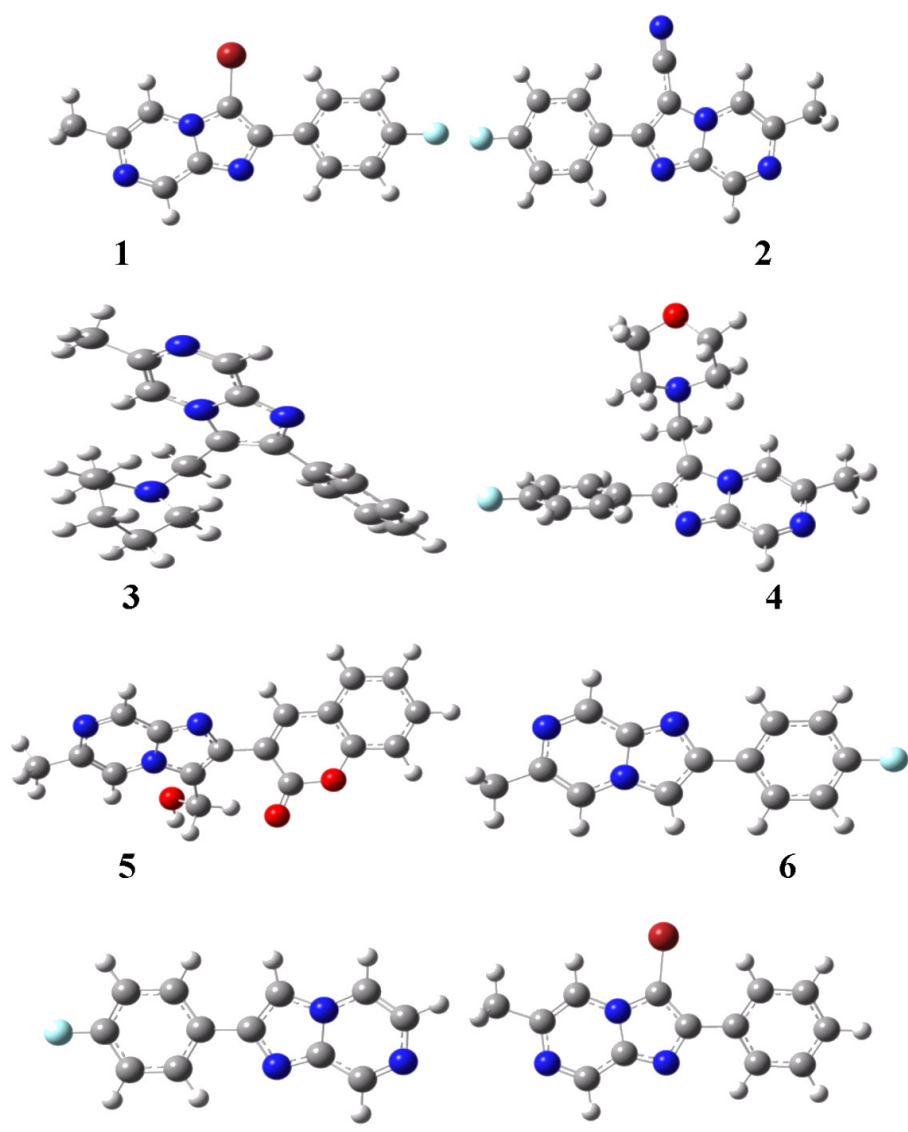

7

8

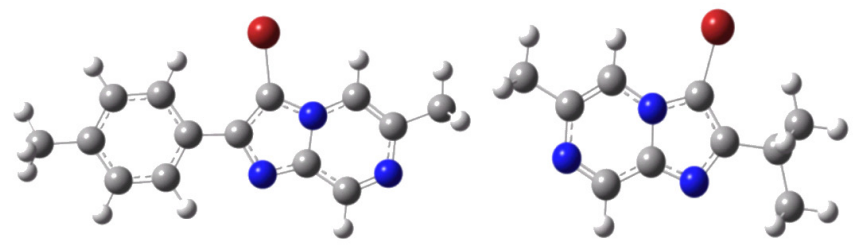

9

10

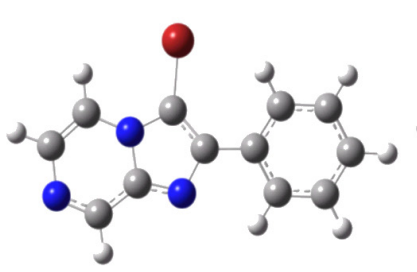

11

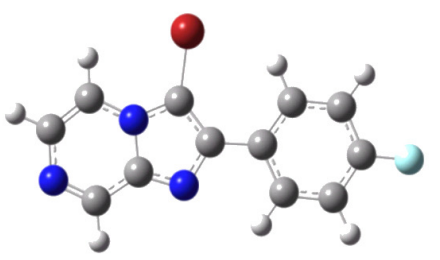

12

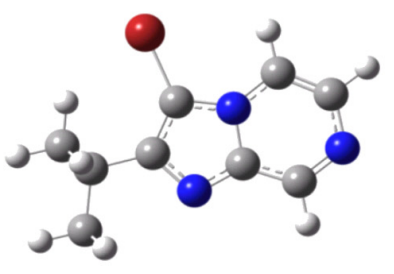

13

Fig. 2. Optimized structure of the studied compounds (1 to 13) obtained by B3LYP/6-31G (d) level.

energies. The ground state energies and oscillator strengths were investigated using TD/DFT, calculations on the fully optimized geometries. In fact, these calculation methods have been successfully applied to other conjugated molecules [8].

\section{Results and discussion}

The result of the optimized structures obtained by B3LYP/6-31G (d) (Fig. 2) shows that they have similar conformations (quasi planar conformation). We found that the modification of several groups attached to 
imidazo[1,2-a]pyrazine does not change the geometric parameters.

Table 1 lists the calculated frontier orbital energies and energy Egap between highest occupied molecular orbital (HOMO) and lowest unoccupied molecular orbital (LUMO) and the $E_{\text {gap }}$ energy of the studied molecules.

Electronic structures are fundamental for interpretation and understanding of the absorption spectra. It is deduced that the substitution of imidazo[1,2-a]pyrazine in the molecule 1 by different other substituent groups, push up/down the HOMO/LUMO energies in agreement with their electron acceptor/donor character. As shown in Table 2, the HOMO and LUMO energies of 1 to 13 change significantly. This implies that different side substituent structures play key role in electronic properties and the effect of slight structural variations, especially the effect of the motifs branched to the imidazo[1,2-a]pyrazine on the HOMO and LUMO energies is clearly seen. In addition, the energies of $E_{\text {gap }}$ of the studied molecules differ slightly from $3.915 \mathrm{eV}$ to $4.806 \mathrm{eV}$ depending on the different structures.
It is known that the architecture of photoactive layer is one of the principle factors of the efficiencies of solar cells. The most efficient technique to generate free charge carriers is bulk heterojunction where the $\pi$ conjugated compounds donors are blended with fullerene derivatives as acceptor [9]. In our study, PCEM and derivatives $\left(C_{60}\right.$, $C_{70}, C_{76}, C_{78}-C_{2 \mathrm{~V}}, C_{78}-D_{3}, C_{84}-D_{2}$ ) were included for comparison purposes.

As shown in Table 1, both HOMO and LUMO levels of the studied molecules agree well with the requirement for an efficient photosensitizer. It should be noted that the LUMO levels of the studied compounds $\mathrm{Mi}$ ( $i=1-13)$ are higher than that of PCEM derivatives which varies from -4.0 to $-3.47 \mathrm{eV}\left(C_{60}(-3.47 \mathrm{eV}), C_{70}(-3.54), C_{76}\right.$ (-3.79), $C_{78}-C_{2 \mathrm{~V}}(-3.94), C_{78}-D_{3}(-4.0)$, $\left.C_{84}-D_{2}(-3.98)\right)$ [10].

The maximum open circuit voltage $\left(V_{o c}\right)$ of the BHJ solar cell is related to the difference between the highest occupied molecular orbital (HOMO) of the donor (our studied molecules) and the LUMO of the electron acceptor (PCEM derivatives in our case), taking into account the energy lost during photo-charge generation [11]. The

Table 1. Theoretical electronic properties of the studied compounds calculated from the optimized structures by B3LYP/6-31G. Isodensity plots of the frontier orbital HOMO and LUMO of the studied compounds obtained at B3LYP/6-31(d) level

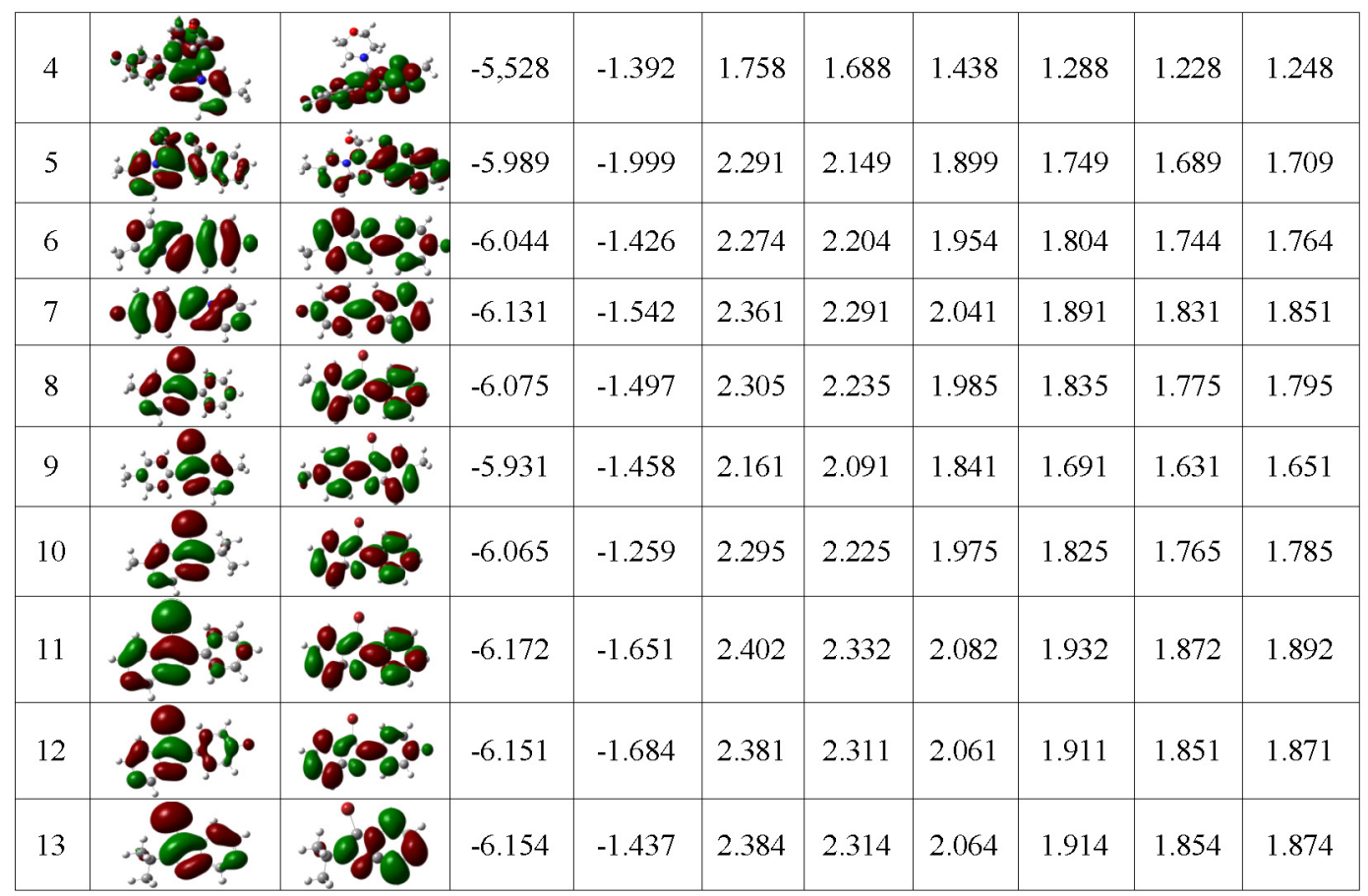


Table 2. Absorption spectra data obtained by TD-DFT methods for the Molecules (1 to 13 ) of the studied compounds at B3LYP/6-31G (d) optimized geometries

\begin{tabular}{||c|c|c|c|c||}
\hline $\mathrm{Mi}$ & $\begin{array}{c}\lambda_{A b s}, \\
(\mathrm{~nm})\end{array}$ & $f$, a.u. & $\begin{array}{c}\lambda_{\text {Emiss }}, \\
(\mathrm{nm})\end{array}$ & $\begin{array}{c}\text { Stockes } \\
\text { Shift, nm }\end{array}$ \\
\hline 1 & 308.92 & 0.2093 & 339.95 & 31.03 \\
2 & 321.44 & 0.0324 & - & - \\
3 & 376.36 & 0.0061 & - & - \\
4 & 351.83 & 0.0157 & - & - \\
5 & 354.27 & 0.1128 & 391.95 & 37.68 \\
6 & 298.92 & 0.2545 & - & - \\
7 & 300.85 & 0.2577 & 331.48 & 30.63 \\
8 & 306.19 & 0.1783 & 348.58 & 42.39 \\
9 & 311.09 & 0.2448 & 334.48 & 23.39 \\
10 & 289.82 & 0.0733 & 332.33 & 42.51 \\
11 & 309.77 & 0.1851 & 436.01 & 126.24 \\
12 & 311.53 & 0.2122 & 342.43 & 30.90 \\
13 & 297.67 & 0.0824 & 332.99 & 35.32 \\
\hline
\end{tabular}

theoretical values of open-circuit voltage $V_{o c}$ have been calculated from the following expression:

$$
\begin{gathered}
V_{o c}= \\
=\left|E_{\text {HOMd Dono })|-|}\right| E_{L U M d}(\text { Acceptor }) \mid-0.3 .
\end{gathered}
$$

The obtained values of $V_{o c}$ of the studied molecules calculated according to the equation (1) range from $1.407 \mathrm{eV}$ to $2.603 \mathrm{eV}$ (see Table 1). These values are sufficient for a possible efficient electron injection to PCEM derivatives. Therefore, all the studied molecules can be used as sensitizers. We noted that the best values of $V_{o c}$ are indicated for the studied compounds (1-13) blended with $C_{60}$ or $C_{70}$ and higher value are given for molecule 2 blended with $C_{60}$ (2.603 eV).

The frontier molecular orbital (MO) contribution is very important in determining the charge-separated states of the studied molecules because the relative ordering of occupied and virtual orbital provides a reasonable qualitative indication of excitations properties [12]. In general, as shown in Table 1, the HOMOs of these molecules in the neutral form possess $\pi$-bonding character and $\pi$-antibonding character between the consecutive subunits while the LUMOs possess $\pi$-antibonding character and $\pi$-bonding character between the subunits whereas it is the opposite in the case of doped forms.
We have calculated UV-visible spectra of the studied compounds using TD-DFT starting with optimized geometry obtained at B3LYP/6-31(d) level. As illustrated in Table 2, we can find the values of calculated wavelength $\lambda_{\max }(a b s)$ and oscillator strengths $f$. Excitation to the $S_{1}$ state corresponds almost exclusively to the promotion of an electron from the HOMO to the LUMO orbital. The absorption wavelengths arising from $S_{0} \rightarrow S_{1}$ electronic transition increase progressively with the increasing of conjugation lengths. It is reasonable, since HOMO $\rightarrow$ LUMO transition is predominant in $S_{0} \rightarrow S_{1}$ electronic transition; the results are a decrease of the LUMO and an increase of the HOMO energy. Data in Table 2 shows that there is a bathochromic shift when passing from Molecule 10 (289.82 nm) to Molecule $3(376 \mathrm{~nm})$. This effect is obviously due to the aromaticity, conjugation and substitution effects in the several studied compounds. Those interesting points are seen both in the studying the electronic and absorption properties.

In order to study the emission photoluminescence properties of the studied compounds $\mathrm{M}_{\mathrm{i}}$, TD/B3LYP method was applied to the geometry of the lowest singlet excited state optimized at the CIS level with 3-21G basis set [13]. As illustrated in Table 2 , this could be regarded as electron transition process that is the reverse of the absorption corresponding mainly to the LUMO-HOMO electron transition configuration. Moreover, the observed red-shifted emission of the $\mathrm{PL}$ spectra is in reasonable agreement with the obtained results of absorption. We can also note that relatively high values of the Stokes Shift (SS) are obtained for Molecule 11 (126.24 nm). In fact, the Stokes Shift, which is defined as the difference between the absorption and emission maximums (EVA-EVE), is usually related to the band widths of both absorption and emission bands [14].

\section{Conclusions}

This study is a theoretical analysis of the geometries and electronic properties of various compounds based on pyrazine which displays the effect of substituted groups on the structural and optoelectronic properties of these materials and leads to the possibility to suggest these materials for organic solar cells application. The concluding remarks are:

The results of the optimized structures for all studied compounds are that they 
have similar conformations (quasi planar conformation). We found that the modification of several groups does not change the geometric parameters. The calculated frontier orbital energies HOMO and LUMO and energy $E_{\text {gap }}$ showed that the energy $E_{\text {gap }}$ of the studied molecules differ slightly from $4.806 \mathrm{eV}$ to $3.99 \mathrm{eV}$ depending on the different structures.

The energy $E_{\text {gap }}$ of molecule 3 is much smaller than that of the other compounds.

The Molecule 11 witch have a relatively high value of $\lambda_{\max }$ (absorption), $\lambda_{\max }$ (emission) and the Stokes Shift (SS) is expected to have the most outstanding photophysical properties.

All the studied molecules can be used as sensitizers because the electron injection process from the excited molecule to the conduction band of PCEM and derivatives and the subsequent regeneration are feasible in the organic sensitized solar cell. The best values of $V_{o c}$ are obtained for the studied compounds (1-13) blended with $C_{60}$ or $C_{70}$ and the higher value are given for molecule 2 blended with $C_{60}(2.603 \mathrm{eV})$.

This calculation procedure can be used as a model system for understanding the relationships between electronic properties and molecular structure and also can be employed to explore their suitability in electroluminescent devices and in related applications. Presumably, the procedures of theoretical calculations can be employed to predict and assume the electronic properties on yet prepared and efficiency proved the other materials, and further to design new materials for the organic solar cells.

Acknowledgements. We are grateful to the "Association Marocaine des Chimistes Theoriciens" (AMCT).

\section{References}

1. H.Shirakawa, E.J.Louis, A.G.Macdiarmid et al., Chem.Soc., 16, 578 (1978); H.Shirakawa, Synthetic Metals, 125, 3 (2001).

2. W.Wu, Y.Liu, D.Zhu, Chem.Soc. Rev., 38, (2009); A.Facchetti, Rev.Chem.Mater., 23, 733 (2011).

3. J.Hou, M.Park, S.Zhang et al., Macromolecules, 41, 6012 (2008).

4. C.Li, M.Liu, N.G.Pschirer et al., Chem.Rev., 110, 6817 (2010).

5. C.Lee, W.Yang, R.G.Parr, Phys.Rev., 37, 785 (1988).

6. A.D.Becke, Density.J.Chem.Phys., 98, 5648 (1993).

7. M.J.Frisch, G.W.Trucks, H.B.Schlegel et al., Gaussian 09, Gaussian Inc., Wallingford, CT (2009).

8. M.Zerner, Reviews in Computational Chemistry, v.2, ed. by K.B.Lipkowitz and D.B.Boyd, VCH, New York (1991); S.Bouzakraoui, S.M.Bouzzine, M.Bouachrine et al., Sol.Cel., 90, 1393 (2006); S.Bouzakraoui, S.M.Bouzzine, M.Bouachrine, M.J.Hamidi, J.Mol. Struct.(Theochem), 725, 39 (2005); H.Zgou, S.M.Bouzzine, S.Bouzakraoui et al., Chinese Chemical Letters, 19, 123 (2008); S.M.Bouzzine, A.Makayssi, M.Hamidi, M.Bouachrine, $J$. Mol. Struct. (Theochem), 851, 254 (2008).

9. H.Derouiche, V.Djara, Sol.Energy Mater. Sol. Cells, 91, 1163 (2007); L.Zhang, L.Zhang, H.Yan et al., Sol. Energy Mater. Sol. Cells, 92, 581 (2008).

10. P.Morvillo, Solar Energy Mater. Solar Cells, 93, 1827 (2009).

11. S.Bertho, I.Haeldermans, A.Swinnen et al., Energy Mater.Sol.Cells, 91, 385 (2007).

12. S.Gunes, H.Neugebauer, N.S.Sariciftci, Chem. Rev., 107, 1324 (2007).

13. S.He-ping, D.Jian-xin, S.Li-wen et al., Spectrochimica Acta Part., 93, 19 (2012).

14 S.Kato, T.Matsumoto, M.Shigeiwa et al., Chem. Eur.J., 12, 2303 (2006).

15. A.Azazi, A.Mabrouk, K.Alimi, Comp. Theor. Chem., 978, 7 (2011). 